\title{
The effect of operational conditions on the hydrodynamic characteristics of the sludge bed in UASB reactors
}

\author{
R. C. Leitão ${ }^{1}$, S. T. Santaellla ${ }^{2}$, A. C. van Haandel $^{3}$, G. Zeeman ${ }^{4}$ and G. Lettinga ${ }^{4}$
}

1 Embrapa Agroind. Tropical, R. Cel. Juca, 510, Fortaleza, 60170-320, Brazil, renato@ cnpat.embrapa.br

2 Sea Science Institute, Federal University of Ceará, Brazil, sandra@ufc.br

3 Dept. Civil Engineering, Federal University of Campina Grande, C Grande, Brazil, prosab@uol.com.br

4 Dept. Envir. Technology, Wageningen Univ., Netherlands, grietje.zeeman@wur.nl, gatze.lettinga@wur.nl

\begin{abstract}
This work aims to evaluate the hydrodynamic properties of the sludge bed of Upflow Anaerobic Sludge Blanket (UASB) reactors based on its settleability and expansion characteristics. The methodologies used for the evaluation of the settleability of aerobic activated sludge, and for the expansibility of a sludge bed of Expanded Granular Sludge Bed reactors and Fluidised Bed Reactors were adapted and applied to the particular characteristics of the sludge of UASB reactors. An easy-to-build experimental set-up was developed to assess the parameters necessary for the equations of settleability and of expansibility. The results obtained from the sludges of seven differently operated reactors show that settleability increased and expansibility decreased at decreased hydraulic retention time and/or increased influent concentrations. The results also show that it is to no avail to design an UASB reactor with a longer HRT to cope with hydraulic shock loads.
\end{abstract}

\section{Keywords}

Expansibility; HRT; influent concentration; settleability; SVI; UASB reactors.

\section{INTRODUCTION}

One of the main advantages of the Anaerobic Upflow Sludge Blanket (UASB) reactor is its capacity to retain a high quantity of viable biomass under operational conditions, resulting in a sludge age that is much longer than the hydraulic retention time (HRT). This is a result of the highly settleable type of biomass that develops in the system.

One of the parameters frequently used to evaluate the settleability of an anaerobic sludge is the Sludge Volume Index (SVI). However, the use of SVI is controversial. According to several authors (Van Haandel and Van der Lubbe, 2007, Giokas et al., 2003; Jin et al., 2003; Dick and Vesilind, 1969), SVI has a bad correlation with the settleability characteristics of aerobic sludge. The latter authors also agreed that a more accurate procedure for the evaluation of the settleability seems to be the one developed by Vesilind (1968), which is based on the relationship between the solids zone settling velocity (ZSV) and the sludge concentration. This method generates two empirical parameters, namely " $\mathrm{k}$ " and " $\mathrm{U}_{\mathrm{S}, 0}$ ", which provide insight into the hydrodynamics of the aerobic sludge flocks. However, the use of this kind of test for anaerobic sludge is so far not reported. In this case, other methods were used to assess the settleability by using SVI (Martínez et al., 2001; Ince et al., 2001; Wang and Shen, 2000); Yun et al., 2000), Paques (Liu et al., 2006) and settleometer (Poinapen et al., 2009).

An important characteristic of anaerobic reactors, operated in an upward-stream mode, is the expansibility of the sludge bed. Several papers deal with sludge bed expansion, but only for Expanded Granular Sludge Bed (EGSB) and Fluidised Bed Reactors (FBR), for instance, Liu et al. (2006), Saravanan and Sreekrishnan (2005), Nicolella et al. (1999), and Marín et al. (1999) used methods based on Richardson and Zaki (1954). Particularly for UASB reactors, sludge bed characteristics may be related to the capacity of the reactor to retain the sludge. In fact, the hydrodynamic behaviour of the sludge bed in UASB reactors is still not clear, and the appropriate sludge bed height or the space between the sludge bed and the phase separator has been designed by trial and error.

This work aims to evaluate the hydrodynamic properties of the UASB sludge bed based on its settleability and expansibility. To achieve this goal, the methodologies used for the evaluation of the 
settleability of aerobic activated sludge, and for the expansibility of the sludge bed of EGSB and FBR reactors were adapted and applied to the particular characteristics of the sludge of UASB reactors. Sludge samples obtained from pilot-scale UASB reactors were used to test and evaluate the effects of different operational conditions on the hydrodynamic properties of anaerobic sludge.

\section{MATERIALS AND METHODS}

\section{Anaerobic Sludge}

The experimental investigation was carried out, using sludge obtained from seven pilot-scale UASB reactors (volume of $120 \mathrm{~L}$ and height of $4 \mathrm{~m}$ ), which were fed with domestic sewage at a temperature of around $27^{\circ} \mathrm{C}$. They were denominated by $\mathrm{R}_{\mathrm{COD}}^{\mathrm{HRT}}$, where the superscript index stands for the hydraulic retention time, and the subscript index stands for the total influent Chemical Oxygen Demand (COD), both are the average during the "steady state" conditions. The main operational parameters are presented in Table 1.

When "steady state" was established, the sludge was withdrawn from taps located at 4 heights of the reactors $(0.25,1.00,1.75$ and 2.50 meters from the bottom) to assemble composite samples, which were used in the lab-scale reactors.

Table 1. Operational parameters of the pilot-scale UASB reactors from where the tested sludges were withdrawn. \pm values are Confidence Intervals $(\alpha=0.05)$.

\begin{tabular}{lccccccc}
\hline \multicolumn{1}{c}{ Reactor } & $\mathrm{R}_{816}^{6}$ & $\mathrm{R}_{770}^{4}$ & $\mathrm{R}_{787}^{2}$ & $\mathrm{R}_{716}^{1}$ & $\mathrm{R}_{558}^{4}$ & $\mathrm{R}_{352}^{2}$ & $\mathrm{R}_{136}^{1}$ \\
\hline HRT (h) & 6 & 4 & 2 & 1 & 4 & 2 & 1 \\
$\mathrm{U}(\mathrm{m} / \mathrm{h})$ & 0.64 & 0.95 & 1.90 & 3.80 & 0.95 & 1.90 & 3.80 \\
$\mathrm{COD}_{\text {Inf }}(\mathrm{mg} / \mathrm{L})$ & $816 \pm 45$ & $770 \pm 38$ & $787 \pm 31$ & $716 \pm 42$ & $558 \pm 31$ & $352 \pm 18$ & $136 \pm 18$ \\
$\mathrm{COD}_{\mathrm{SS}}(\mathrm{mg} / \mathrm{L})$ & $566 \pm 28$ & $459 \pm 22$ & $513 \pm 20$ & $486 \pm 28$ & $383 \pm 19$ & $235 \pm 13$ & - \\
$\mathrm{COD}_{\text {Dis }}(\mathrm{mg} / \mathrm{L})$ & $250 \pm 73$ & $311 \pm 60$ & $274 \pm 51$ & $230 \pm 70$ & $175 \pm 50$ & $117 \pm 31$ & - \\
\hline
\end{tabular}

$\mathrm{COD}_{\text {Inf }}=$ Total Influent COD; $\mathrm{COD}_{\mathrm{SS}}=$ Influent suspended solids in term of COD; $\mathrm{COD}_{\text {Dis }}=$ Dissolved influent COD. Obs.: Suspended and Dissolved COD of Reator $\mathrm{R}^{1}{ }_{136}$ were not measured.

\section{Lab-Scale Reactors}

The experimental set-up comprised of two lab-scale UASB reactors constructed from plexiglass tubes, with a volume of $7.8 \mathrm{~L}$, a height of $1.2 \mathrm{~m}$ and internal diameter of $0.08 \mathrm{~m}$. The reactors were provided with a modified gas-solid-liquid separator as described by Leitão (2004), and equipped with a recirculation pump. A slowly rotating stirrer $(1 \mathrm{rpm})$ was installed in the lab-scale reactors to avoid channelling and "piston" formation in the sludge bed.

\section{Experimental Procedure}

Composite samples of the sludges generated in the $120 \mathrm{~L}$ plants were analysed for total solids (TS), volatile solids (VS), and SVI prior to the test in the lab-scale reactors. $2.5 \mathrm{~L}$ of this composite sample were used in each of the two lab-scale reactors (the experiments were done in duplicate). Next, the reactors were filled up with anaerobically treated effluent and recirculation was started. By adjusting the recirculation rate, the applied upflow velocity $(\mathrm{U})$ was the same as in the pilotscale reactor from which the sludge was withdrawn. This operational condition was maintained until almost no gas was released. Subsequently, U was increased or decreased, by re-adjusting the recirculation pumps. Data of sludge bed heights and times were collected until there was almost no variation in the bed height. $U$ was increased until the sludge bed reached the gas-liquid-solid separator, and decreased by factors of $0.5,0.75$ and finally recirculation was stopped $(\mathrm{U}=0 \mathrm{~m} / \mathrm{h})$, and the minimum height was observed. 
All physical-chemical analyses were performed as recommended by APHA (1995). The SVI assessed in this work refers to the diluted SVI developed by Stobbe (1964).

\section{RESULTS AND DISCUSSION}

An example of results that can be obtained using the aforementioned methodology is depicted in Figure 1A, where the sludge samples withdrawn from the pilot-scale reactor $\mathrm{R}_{716}^{1}$ (operated with upflow velocity of $3.80 \mathrm{~m} / \mathrm{h}$ ) was tested for different upflow velocities in the lab-scale reactors. During tests, the upflow velocity (U) in the lab-scale reactor was first adjusted to $3.80 \mathrm{~m} / \mathrm{h}$ (the same upflow velocity imposed to the pilot-scale reactor $\mathrm{R}^{1}{ }_{716}$ ). After a certain time, the gas production stopped and the height of the sludge bed stabilised at a level of $46.5 \mathrm{~cm}$ (see dashed line in Figure 1A). The upflow velocity was then set at $5.70 \mathrm{~m} / \mathrm{h}$ until the sludge bed stabilised at another level $(51.5 \mathrm{~cm})$, and subsequently the pump was again set at $3.8 \mathrm{~m} / \mathrm{h}$ until the level of the bed achieved its former position. This procedure was repeated for upflow velocities of 1.90 and $0.95 \mathrm{~m} / \mathrm{h}$. The case of $\mathrm{U}=0 \mathrm{~m} / \mathrm{h}$ was also tested, which represents the maximum contraction of the sludge. In Figure $1 \mathrm{~B}$ the results of the sludge bed height after stabilisation for each upflow velocity is depicted. Sludges taken from all reactors mentioned in Table 1 were tested following this procedure.
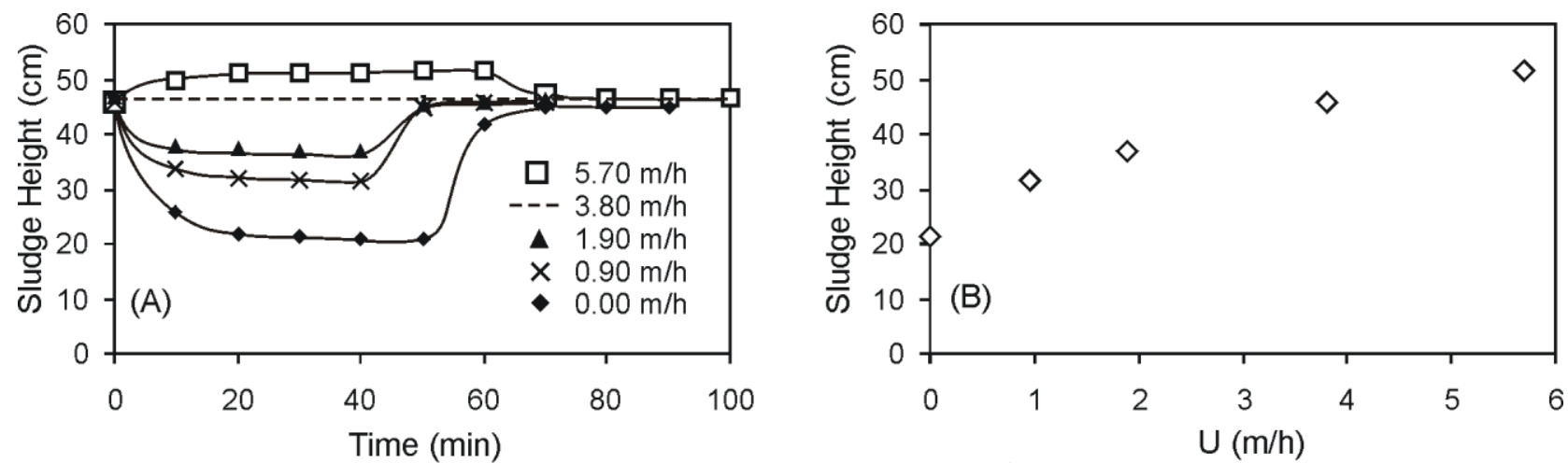

Figure 1. Variation of the sludge bed height (sludge taken from reactor $\mathrm{R}^{1}{ }_{716}$ ) due to changes in upflow velocity (U). (A) Variation with time; dashed line represents the normal upflow velocity in the pilot-scale reactor R1716. (B) Sludge height for different upflow velocities applied to the lab-scale reactors after stabilisation of the expansion or contraction.

\section{Sludge Settleability}

As mentioned before, sludge concentration of the composite sample was determined prior to conducting any tests, and consequently the sludge mass was known. Since the volume of the sludge bed is proportional to the bed height, there was a different volume for each $\mathrm{U}$, and accordingly a different sludge bed concentration (X).

With the calculated results of $X$ and the method developed by Vesilind (1968), viz. plotting $\operatorname{Ln}(\mathrm{U})$ versus $\mathrm{X}$, a straight line results using the least squares method. Based on this line, a direct relationship is obtained, as presented in Equations 1 to 4. Results are presented in Table 2.

$$
\begin{aligned}
& X=\frac{X_{0} \times V_{0}}{A \times h} \\
& L n(U)=k . X+a \\
& U=U_{S, 0} \times e^{-(k . X)} \\
& U_{S, 0}=e^{a}
\end{aligned}
$$

where $X$ is the sludge concentration for a given sludge bed height $(g / L) ; X_{0}$ is the sludge concentration of the composite sample $(\mathrm{g} / \mathrm{L}) ; \mathrm{V}_{0}$ is the volume of sludge used for the experiment; 
" $\mathrm{A}$ " is the cross-section area of the lab-scale reactor $\left(0.5 \mathrm{dm}^{2}\right)$; and $\mathrm{h}(\mathrm{dm})$ is the height of the sludge for a given upflow velocity; $\mathrm{U}_{\mathrm{S}, 0}(\mathrm{~m} / \mathrm{h})$ and $\mathrm{k}(\mathrm{L} / \mathrm{g})$ are the Vesilind empirical constants; $\mathrm{U}$ is the upflow velocity $(\mathrm{m} / \mathrm{h})$; and "a" is an empirical constant.

Table 2. Operational parameters of the pilot-scale UASB reactors from where the tested sludges were withdrawn, and calculated constants for sludge settleability.

\begin{tabular}{lccccccc}
\hline \multicolumn{1}{c}{ Reactor } & $\mathrm{R}_{816}^{6}$ & $\mathrm{R}_{770}^{4}$ & $\mathrm{R}_{787}^{2}$ & $\mathrm{R}_{716}^{1}$ & $\mathrm{R}_{558}^{4}$ & $\mathrm{R}_{352}^{2}$ & $\mathrm{R}_{136}^{1}$ \\
\hline $\mathrm{SVI}$ & 18 & 21 & 22 & 16 & 18 & 18 & 23 \\
$\mathrm{a}$ & 2.785 & 2.386 & 2.907 & 4.905 & 2.417 & 2.144 & 3.839 \\
$\mathrm{X}_{0}(\mathrm{~g} / \mathrm{L})$ & 37.37 & 35.16 & 35.15 & 35.01 & 33.82 & 29.15 & 15.14 \\
$\mathrm{~V}_{0}(\mathrm{~L})$ & 2.5 & 2.5 & 2.5 & 2.5 & 2.5 & 2.0 & 2.5 \\
$\mathrm{k}(\mathrm{L} / \mathrm{g})$ & 0.131 & 0.097 & 0.105 & 0.128 & 0.081 & 0.134 & 0.204 \\
$\mathrm{U}_{\mathrm{S}, 0}(\mathrm{~m} / \mathrm{h})$ & 16 & 11 & 18 & 135 & 11 & 9 & 47 \\
\hline
\end{tabular}

Figure 2A depicts the results of the calculated sludge bed concentration $(\mathrm{X})$ and $\mathrm{Ln}(\mathrm{U})$ for all sludge samples taken from the seven UASB reactors. In this figure, the straight line for the sludge of the pilot-scale reactor $\mathrm{R}^{1}{ }_{716}$ was plotted as an example. Figure $2 \mathrm{~B}$ shows the experimental results of the reactors operated at different HRT $\left(\mathrm{R}_{816}^{6}, \mathrm{R}^{4}{ }_{770}, \mathrm{R}^{2}{ }_{787}\right.$, and $\left.\mathrm{R}^{1}{ }_{716}\right)$ and with an influent COD concentration $\left(\mathrm{COD}_{\text {Inf }}\right)$ of around $800 \mathrm{mg} / \mathrm{L}$, together with the calculated relation between $\mathrm{U}$ and $\mathrm{X}$ using Equation 3. The experimental data indicate that as HRT decreases, and hence upflow velocity increases, the settleability of the sludge improves, so that a higher sludge concentration can be kept in the reactor. This is because at equilibrium conditions, viz. a constant sludge bed height, the applied $U$ can be assumed to be equal to the apparent settling velocity of the sludge bed; consequently for a given $\mathrm{U}$ the sludge bed concentration $(\mathrm{X})$ will increase with the settleability of the sludge.
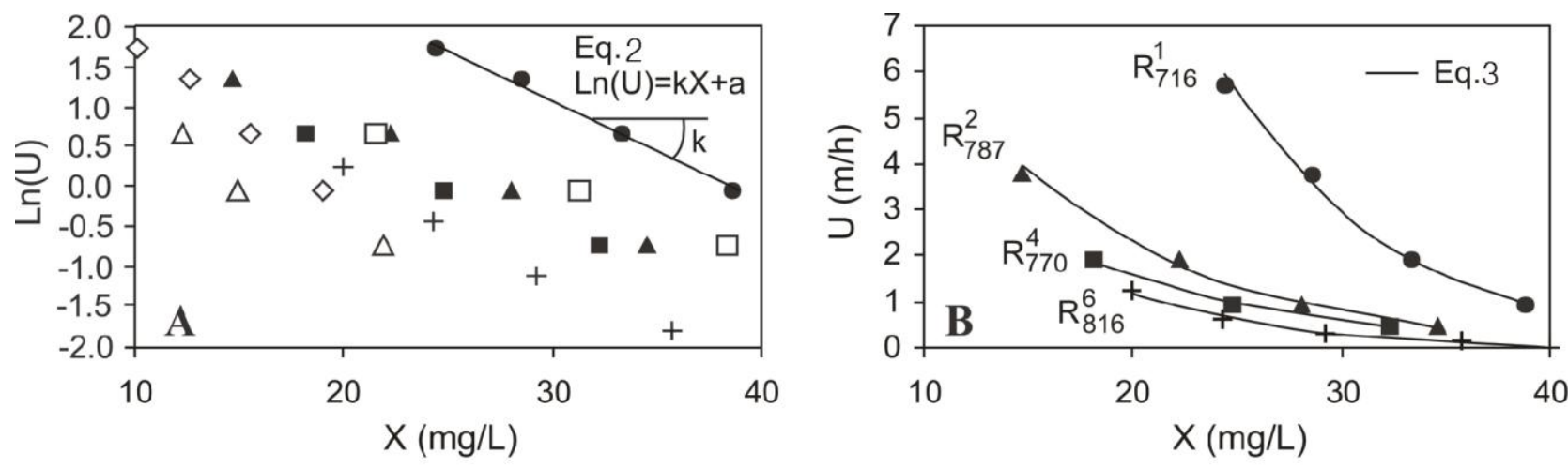

Legend: $\quad+\mathrm{R}_{816}^{6} \quad \mathrm{R}^{4}{ }_{770} \quad \Delta \mathrm{R}_{787}^{2} \quad \bullet \mathrm{R}^{1}{ }_{716} \quad \square \mathrm{R}_{558}^{4} \quad \Delta \mathrm{R}_{352}^{2} \quad \diamond \mathrm{R}^{1}{ }_{136}$

Figure 2. (A) Results of the calculated sludge bed concentration " $X$ " and $\operatorname{Ln}(\mathrm{U})$. (B) Experimental and calculated results of upflow velocity $(\mathrm{U})$ and sludge concentration $(\mathrm{X})$.

The sludge retention in UASB systems is assured by the development of a well-settleable sludge, which counterbalances the drag force by the imposed upflow velocity. Consequently, reactors operated with high upflow velocities are intrinsically capable to cope with such operation and will, by principle, contain sludge with a relatively high settleability. The sludge settleability apparently increased as the HRT decreased (and upflow velocity increased), which is possibly due to the occurrence of a selection process in the sludge bed, i.e. the washout of the voluminous light flocks, leaving the well-settling aggregates in the reactor (O'Flaherty et al., 1997).

When the method for evaluation of settleability was applied to sludge obtained from reactors 
operated at different $\mathrm{COD}_{\text {Inf }}$ (results not shown) the settleability of the sludge increased as the $\mathrm{COD}_{\text {Inf }}$ increased. However these results seem to be true for the operational conditions applied during this research, i.e. "U" in the range of $0.64-3.80 \mathrm{~m} / \mathrm{h}, \mathrm{COD}_{\text {inf }}$ between 136 and $816 \mathrm{mg} / \mathrm{L}$, and $\mathrm{COD}_{\mathrm{SS}}$ below $566 \mathrm{mg} / \mathrm{L}$. Higher upflow velocities can deteriorate the sludge due to shear forces (Bhunia and Ghangrekar, 2008), and influent with high concentration of SS can negatively affect the reactor due to the limiting hydrolysis rate (Halalsheh et al., 2005).

This phenomenon can be due to one of the following factors:

- A low substrate concentration may cause a depletion of the extracellular polymer (ECP) production, known to be one of the responsible factors for sludge granulation or flocculation (Yun et al., 2000). This may lead to a more flocculent and less settleable type of sludge (Mulder, 2003).

- The formation of a more flocculent type of sludge with the application of low concentration influent, and relatively low upflow velocities, may be a result of natural selection, as flocculent sludge is characterized by a lower mass transfer resistance as compared to granular sludge (Nicolella et al., 2000). Therefore, the substrate is more accessible to the biomass in the flocculent sludge.

There was no simple and evident correlation observed either between SVI and the settleability constants (" $\mathrm{k}$ " and "US,0"), or between SVI and the operational parameters (HRT and COD Inf), as shown in Table 2. The SVI is considered as an inferior parameter for characterising the settleability of anaerobic sludge: (i) it is not independent of the sludge concentration, (ii) it is highly affected by the experimental set-up and procedure during the test, (iii) it defines only one point of the settling curve, and (iv) it is intuitively doubtful that two parameters of a model (Equation 3) can be estimated based on only one SVI value from a test performed at a single sludge concentration value (Jin et al., 2003; Giokas et al., 2003; Ekama and Marais, 1986; Dick and Vesilind, 1969). In contrast to activated sludge systems, UASB reactors use sedimentation as the driving force, and as a consequence the values of SVI are very low in comparison to activated sludge. The values of SVI found for the tested anaerobic sludges vary between 16 and $23 \mathrm{~mL} / \mathrm{g}$ which are far below the range usually found for aerobic sludge. In fact, Mohlman (1934) developed the SVI method for evaluation of the settleability of aerobic activated sludge, which SVI ranges from ca. 40 to $400 \mathrm{~mL} / \mathrm{g}$ (Giokas et al., 2003).

The methodology developed by Vesilind (1968), adapted in the present investigation, can be used for the optimisation of systems that use UASB reactors as pre-treatment. When UASB reactors are operated without intentional sludge discharge, as applied in the present research, the produced excess sludge can be removed from a secondary treatment unit, e.g. a secondary settler. The parameters $\mathrm{U}_{\mathrm{S}, 0}$ and $\mathrm{k}$ (Table 2) can be used for the design of this secondary settler. Such an operational procedure of the UASB reactor may improve the filtration capacity of the system, as well as the organic load potential, because the system is operated with its maximum sludge accumulation capacity. Moreover, by removing the sludge from a secondary treatment unit, the risk of undue discharge is avoided and spontaneous discharges from the UASB reactor do not appear in the effluent. Moreover it has been shown that a large part (1/3) of the sludge production is washed out, even if the reactor is no full of sludge (Cavalcanti et al, 1999)

\section{Sludge Bed Expansion}

The expansion of the sludge bed $(\varepsilon)$ was calculated using Equation 6. Using the methodology developed by Richardson and Zaki (1954), $\log (\mathrm{U})$ is plotted versus the calculated values of $\varepsilon$ (Figure 3A). The parameters of the linear equation (Equations 6 to 8) can be calculated from the straight lines obtained, using the least squares method. Results are presented in Table 3.

$$
\varepsilon=\frac{h-h_{0}}{h_{0}} \times 100
$$


$\log (U)=m \times \log (\varepsilon)+b$

$U=U_{E, 0} \times(\varepsilon)^{m}$

$U_{E, 0}=10^{b}$

where: $\varepsilon(\%)$ is the sludge bed expansion; $\mathrm{h}(\mathrm{dm})$ is the established height of the sludge bed for a given upflow velocity; $h_{0}(\mathrm{dm})$ is the height of the sludge when upflow velocity is zero; $U_{E, 0}(\mathrm{~m} / \mathrm{h})$ and " $\mathrm{m}$ " $(\mathrm{L} / \mathrm{g})$ are the expansibility constants; $\mathrm{U}(\mathrm{m} / \mathrm{h})$ is the upflow velocity; and "b" is an empirical constant.

Figure 3B shows the experimental results of the reactors operated at different HRTs $\left(\mathrm{R}_{816}^{6}, \mathrm{R}^{4}{ }_{770}\right.$, $\mathrm{R}^{2}{ }_{787}$, and $\mathrm{R}^{1}{ }_{716}$ ) and at a $\mathrm{COD}_{\text {Inf }}$ of around $800 \mathrm{mg} / \mathrm{L}$, together with the calculated results using Equation 7 (represented in the graph by the continuous line). In this figure, the straight line for the sludge of the pilot-scale reactor $\mathrm{R}_{716}^{1}$ was plotted as an example. When comparing the results of these reactors it is clear that the sludge expansibility declined at a decreasing HRT.

Table 3. Operational parameters of the pilot-scale UASB reactors from where the tested sludges were withdrawn, and calculated constants for sludge expansibility.

\begin{tabular}{lccccccc}
\hline \multicolumn{1}{c}{ Reactor } & $\mathrm{R}_{816}^{6}$ & $\mathrm{R}_{770}^{4}$ & $\mathrm{R}_{787}^{2}$ & $\mathrm{R}_{716}^{1}$ & $\mathrm{R}_{558}^{4}$ & $\mathrm{R}_{352}^{2}$ & $\mathrm{R}_{136}^{1}$ \\
\hline $\mathrm{h}_{0}(\mathrm{~m})$ & 30.5 & 27.8 & 23.8 & 21.5 & 26.4 & 21.0 & 16.4 \\
$\mathrm{~m}(\mathrm{~L} / \mathrm{g})$ & 1.957 & 1.588 & 1.518 & 1.595 & 1.271 & 1.610 & 1.843 \\
$\mathrm{~b}$ & 0.523 & 0.283 & 0.075 & 0.508 & 0.099 & 0.542 & 0.214 \\
$\mathrm{U}_{\mathrm{E}, 0}(\mathrm{~m} / \mathrm{h})$ & 0.3 & 0.5 & 0.8 & 3.2 & 0.8 & 0.3 & 0.6 \\
\hline
\end{tabular}

Sludge expansion is highly related to settleability, and both parameters describe the same hydrodynamic characteristics of the sludge bed. The discussion presented for sludge settleability therefore is also valid for sludge expansion.
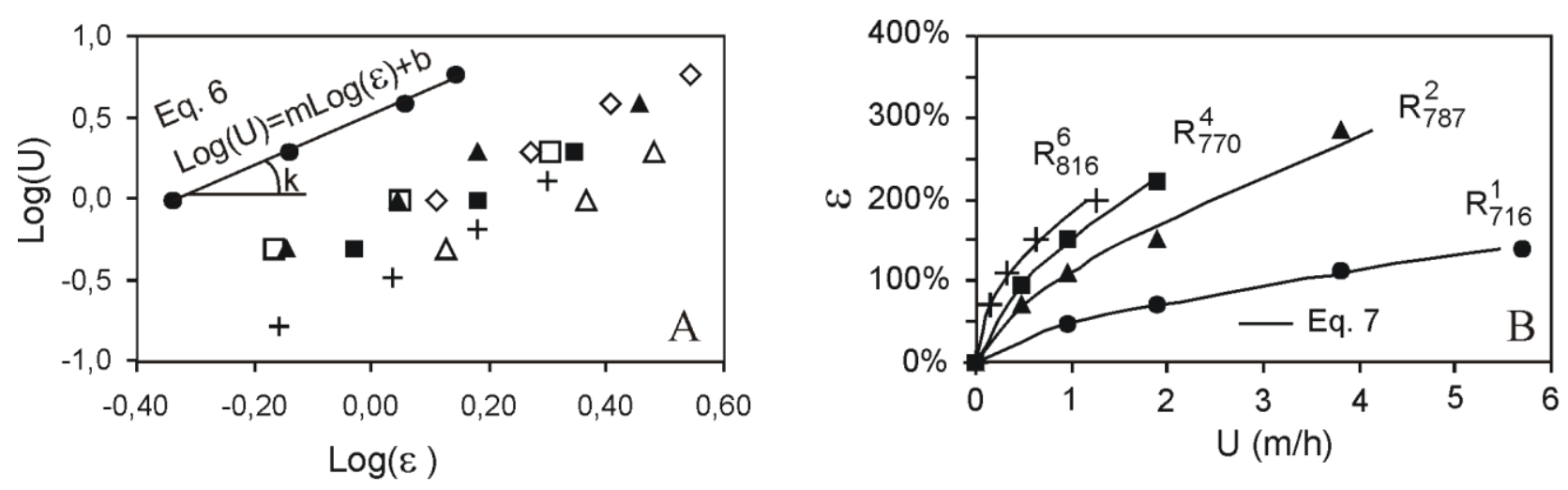

Legend: $+\mathrm{R}_{816}^{6} \quad \mathrm{R}^{4}{ }_{770} \quad \Delta \mathrm{R}^{2}{ }_{787} \quad \bullet \mathrm{R}_{716}^{1} \quad \square \mathrm{R}^{4}{ }_{558} \quad \Delta \mathrm{R}_{352}^{2} \quad \diamond \mathrm{R}^{1}{ }_{136}$

Figure 3. (A) Results of the calculated sludge expansion $(\varepsilon)$ and $\log (\mathrm{U})$. (B) The effect of upflow velocity (U) on the sludge bed expansion $(\varepsilon)$.

The model used for the prediction of the sludge bed expansion, adapted from the equation of Richardson and Zaki (1954), can be applied for the optimisation of the sludge bed height in an UASB reactor in case the reactor is operated with intentional sludge discharge. If the flow rate fluctuation regime is known, it is possible to predict the variation of the sludge bed height. Therefore, it is possible to avoid any substantial sludge washout during a hydraulic overload, which can deteriorate the post treatment step. As an example: assuming that the UASB reactor has to cope with a variation of a factor of 1.5 the average flow rate (usually found in separate sewer systems), 
and using the data of the reactors operated at HRT of 6 and 4 hours (upflow velocity of 0.64 and $0.95 \mathrm{~m} / \mathrm{h}$ respectively) and influent concentration ranging from 500 and $800 \mathrm{mgCOD} / \mathrm{L}$, the optimal sludge bed height (under "steady state" conditions) should be maintained between 70 to $80 \%$ of the distance between the bottom of the reactor and the 3 phase separator.

If the UASB reactors are operated in a mode without intentional sludge discharge, it is possible to quantify the amount of sludge that will be expelled during an imposed hydraulic overload. Thus, either some protective measures can be applied in the post treatment, or the post treatment can be designed in such a way that it can cope with the temporary sludge overload.

The results in this work show that it is of no avails to design a reactor with a longer HRT in order to cope with a hydraulic shock, as a more expansible sludge will develop, which is less able to withstand flow variations.

\section{CONCLUSIONS}

(i) The experimental set-up and the procedure presented in this work are suitable for assessing the settleability of anaerobic sludge in terms of the Vesilind (1968) equation, as well as to estimate the expansion of a sludge bed by using the equation of Richardson and Zaki (1954).

(ii) Decreasing HRTs or increasing upflow velocities lead to increased settleability and decreased expansion of the anaerobic sludge in reactors operated with upflow velocities in the range of $0.64-3.80 \mathrm{~m} / \mathrm{h}, \mathrm{COD}_{\text {inf }}$ between 136 and $816 \mathrm{mg} / \mathrm{L}$, and COD $\mathrm{ss}$ below $566 \mathrm{mg} / \mathrm{L}$.

(iii) Decreasing the influent COD concentration leads to decreased settleability and increased expansion of the anaerobic sludge.

(iv) The settleability test developed in this work can help to design a secondary settler, which can improve the performance of the system.

(v) The expansibility test developed in this work can be used to optimise the sludge bed level, when the UASB reactor has to cope with fluctuating flow rates.

(vi) The SVI parameter cannot be used to compare settleability of different UASB sludges, since this kind of sludge is highly settleable and seems to be out of range for this method.

(vii) It is to no avail to design an UASB reactor with a longer HRT to cope with hydraulic shock loads.

\section{References}

APHA - Standard Methods for the Examination of Water and Wastewater (1995). 19th edn, American Public Health Association/American Water Works Association/Water Environment Federation, Washington DC, USA

Cavalcanti P.F.F., Medeiros E.J.S., Silva J.K.M. and Van Haandel A.C. (1999) Excess sludge discharge frequencyfor UASB reactors Water.Science and.Technology. 40(8), 211-219

Dick, R. I. and Vesilind, P. A. (1969). The Sludge Volume Index - What is it? Journal of Water Pollution Control Federation. 41(7), $1285-1291$.

Ekama, G. A. and Marais, G. V. R. (1986). Sludge settleability and secondary settling tank design procedures. Water Pollution Control. 85, 101-113.

Giokas, D. L., Daigger, G. T., von Sperling, M., KIm, Y. and Paraskevas, P. A. (2003). Comparison and evaluation of empirical Zone Settling Velocity parameters based on Sludge Volume Index using a unified settling characteristics database. Water Research. 37(16), 3821-3836.

Ince, O., Ince, B. K. and Yenigun, O. (2001). Determination of potential methane production capacity of a granular sludge from a pilot-scale upflow anaerobic sludge blanket reactor using a specific methanogenic activity test. Journal of Chemical Technology and Biotechnology. 76, 573-578.

Jin, B., Wilén, B. M. and Lant, P. (2003). A comprehensive insight into floc characteristics and their impact on compressibility and settleability of activated sludge. Chemical Engineering Journal. 95(1-3), 221-234.

Leitão, R. C. (2004). Robustness of UASB reactors treating sewage under tropical conditions. PhD thesis, Depto of Environmental Technology, Wageningen University, Wageningen, the Netherlands.

Liu, Y. H.; He, Y. L., Yang, S. C. and Li, Y. Z. (2006a). The settling characteristics and mean settling velocity of granular sludge in upflow anaerobic sludge blanket (UASB)-like reactors. Biotechnology Letters. 28, 1673-1678.

Liu, Y. H.; He Y. L., Yang, S. C. and An, C. J. (2006b). Studies on the expansion characteristics of the granular bed present in EGSB bioreactors. Water SA. 32(4), 555-560.

Marín, P., Alkalay, D., Guerrero, L., Chamy, R. and Schiappacasse, M. C. (1999). Design and startup of an anaerobic fluidized bed reactor. Water Science and Technology. 40(8): 63-70. 
Martínez, J., López, I., Giani, L. and Borzacconi, L. (2001). Blanket development in a malting wastewater anaerobic treatment. Water Science and Technology. 44(4), 57-62.

Mohlman, F. W. (1934). The Sludge Index. Sewage Works Journal. 6(1), 119-125.

Mulder, R. (2003). Biological Wastewater Treatment for Industrial Effluents: Technology and Operation. Paques B.V. Balk. The Netherlands.

Nicolella, C., Van Loosdrecht, M. M. C., Di Felice, R. and Rovatti, M. (1999). Terminal settling velocity and bed-expansion characteristics of biofilm-coated particles. Biotechnology and Bioengineering. 62(1): 62-70.

Nicolella, C., van Loosdrecht, M. C. M. and Heijnen, J. J. (2000). Wastewater treatment with particulate biofilm reactors. Journal of Biotechnology. 80, 1-33.

O'Flaherty, V., Lens, P. N. L., de Beer, D. and Colleran, E. (1997). Effect of feed composition and upflow velocity on aggregate characteristics in anaerobic upflow reactors. Applied Microbiology and Biotechnol. 47(2), 102-107.

Poinapen, J.; Ekama, G. A. and Wentzel, M. C. (2009). Biological sulphate reduction with primary sewage sludge in an upflow anaerobic sludge bed (UASB) reactor - Part 4: Bed settling characteristics. Water SA. 35(5), 553-559.

Richardson, J. F. and Zaki, W. N. (1954). Sedimentation and fluidization. Part I. Transac. Instit. Chem. Engineers. 32, 35-53.

Saravanan, V. and Sreekrishnan, T. R. (2005). Hydrodynamic study of biogranules obtained from an anaerobic hybrid reactor. Biotechnology and Bioengineering, 91(6), 715-721.

Stobbe, G, 1964. Über das Verhalten von belebtem Schlamm in aufsteigender Wasserbewegung. Publication of the Sanitation Engineering Institute of the Technical University of Hanover. 18. 100 p. (in German)

Van Haandel A.C. and Van der Lubbe J (2007) Handbook Bological waste water treatment- Design and optimization of activated sludge systems. Quist Publishing, Leidschendam, Hol.

Vesilind, A., 1968. Design of prototype thickeners from batch settling tests. Water and Sewage Works. 115, 302-307.

Wang, B. and Shen, Y. (2000). Performance of an anaerobic baffled reactor (ABR) as a hydrolysis-acidogenesis unit in treating landfill leachate mixed with municipal sewage. Water Science and Technology. 42(12), 115-121.

Yun, Z., Jo, W., Yi, Y., Choi, S., Choi, E. and Min, K., (2000). Effects of sludge settling characteristics in the BNR system. Water Science and Technology. 42(3-4), 283-288. 

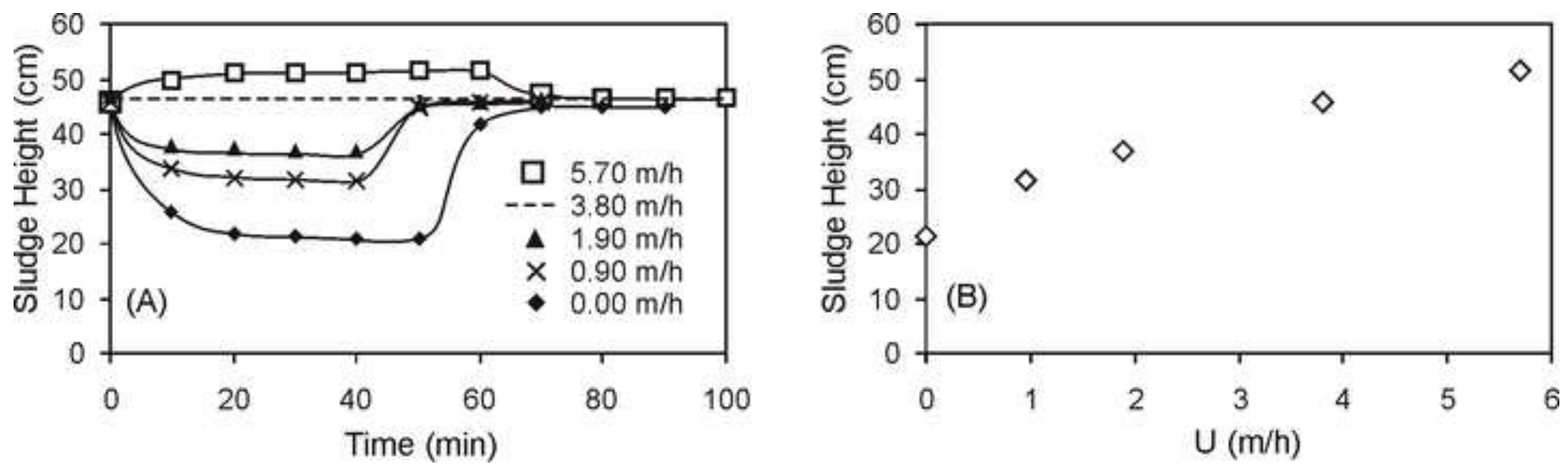

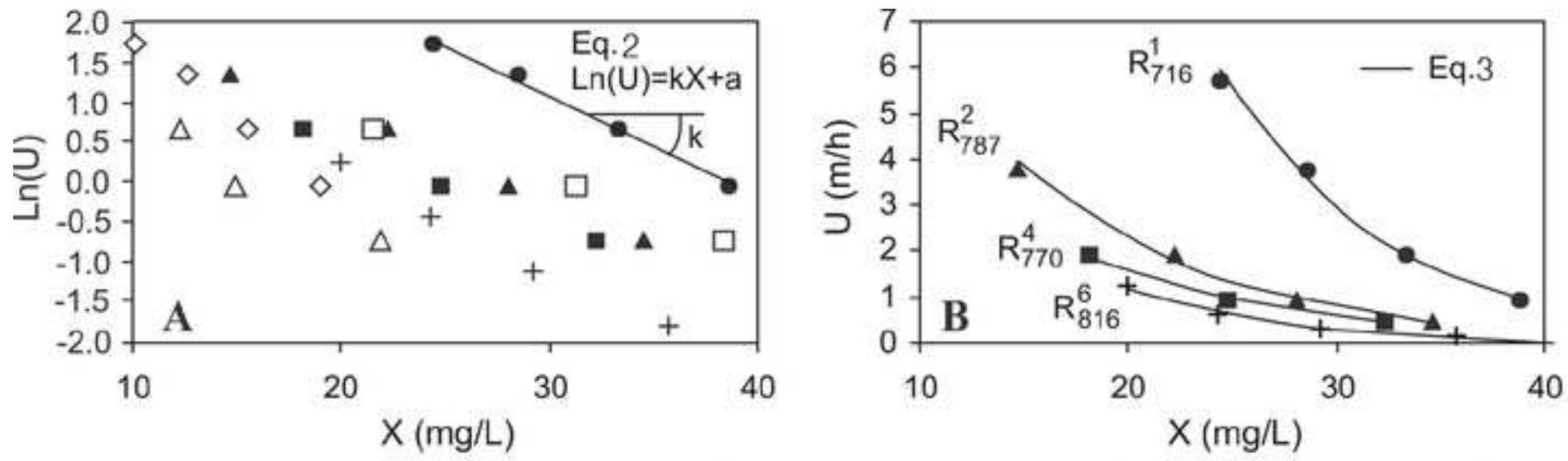

Legend: $+\mathrm{R}^{6}{ }_{816}$ ॥ $\mathrm{R}_{770}^{4} \quad \Delta \mathrm{R}_{787}^{2}$

- $\mathrm{R}^{1} 716$

$\square \mathrm{R}_{558}^{4}$

$\Delta \mathrm{R}^{2}{ }_{352}$

$\Delta \mathrm{R}^{1}{ }_{136}$ 

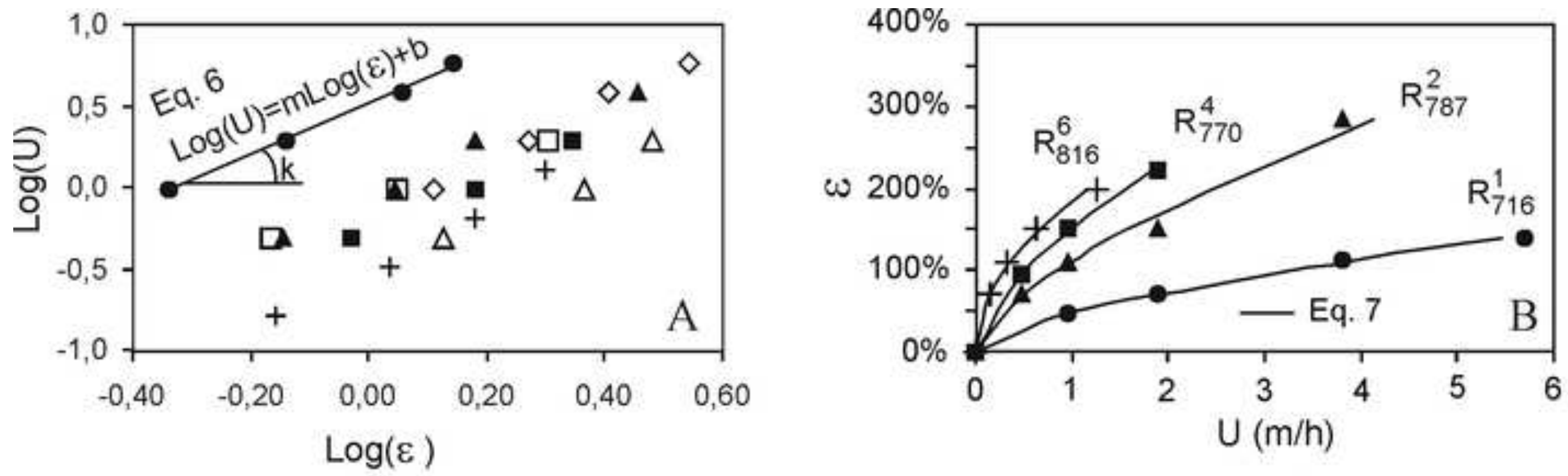

Legend: $+\mathrm{R}_{816}^{6} \quad \mathrm{R}^{4}{ }_{770} \quad \Delta \mathrm{R}^{2}{ }_{787}$

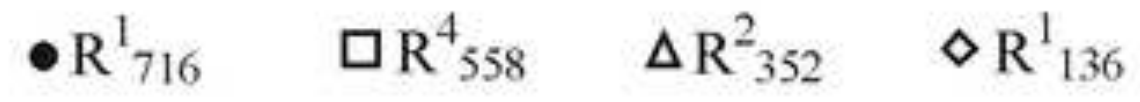


Table 1. Operational parameters of the pilot-scale UASB reactors from where the tested sludges were withdrawn. \pm values are Confidence Intervals $(\alpha=0.05)$.

\begin{tabular}{lccccccc}
\hline \multicolumn{1}{c}{ Reactor } & $\mathrm{R}_{816}^{6}$ & $\mathrm{R}_{770}^{4}$ & $\mathrm{R}_{787}^{2}$ & $\mathrm{R}_{716}^{1}$ & $\mathrm{R}_{558}^{4}$ & $\mathrm{R}_{352}^{2}$ & $\mathrm{R}_{136}^{1}$ \\
\hline $\mathrm{HRT}(\mathrm{h})$ & 6 & 4 & 2 & 1 & 4 & 2 & 1 \\
$\mathrm{U}(\mathrm{m} / \mathrm{h})$ & 0.64 & 0.95 & 1.90 & 3.80 & 0.95 & 1.90 & 3.80 \\
$\mathrm{COD}_{\text {Inf }}(\mathrm{mg} / \mathrm{L})$ & $816 \pm 45$ & $770 \pm 38$ & $787 \pm 31$ & $716 \pm 42$ & $558 \pm 31$ & $352 \pm 18$ & $136 \pm 18$ \\
$\mathrm{COD}_{\text {SS }}(\mathrm{mg} / \mathrm{L})$ & $566 \pm 28$ & $459 \pm 22$ & $513 \pm 20$ & $486 \pm 28$ & $383 \pm 19$ & $235 \pm 13$ & - \\
$\mathrm{COD}_{\text {Dis }}(\mathrm{mg} / \mathrm{L})$ & $250 \pm 73$ & $311 \pm 60$ & $274 \pm 51$ & $230 \pm 70$ & $175 \pm 50$ & $117 \pm 31$ & - \\
\hline
\end{tabular}

$\mathrm{COD}_{\text {Inf }}=$ Total Influent COD; $\mathrm{COD}_{\mathrm{SS}}=$ Influent suspended solids in term of COD; $\mathrm{COD}_{\text {Dis }}=$ Dissolved influent COD. Obs.: Suspended and Dissolved COD of Reator $\mathrm{R}^{1}{ }_{136}$ were not measured. 
Table 2. Operational parameters of the pilot-scale UASB reactors from where the tested sludges were withdrawn, and calculated constants for sludge settleability.

\begin{tabular}{lccccccc}
\hline \multicolumn{1}{c}{ Reactor } & $\mathrm{R}_{816}^{6}$ & $\mathrm{R}_{770}^{4}$ & $\mathrm{R}_{787}^{2}$ & $\mathrm{R}^{1}{ }_{716}$ & $\mathrm{R}_{558}^{4}$ & $\mathrm{R}_{352}^{2}$ & $\mathrm{R}_{136}^{1}$ \\
\hline $\mathrm{SVI}$ & 18 & 21 & 22 & 16 & 18 & 18 & 23 \\
$\mathrm{a}$ & 2.785 & 2.386 & 2.907 & 4.905 & 2.417 & 2.144 & 3.839 \\
$\mathrm{X}_{0}(\mathrm{~g} / \mathrm{L})$ & 37.37 & 35.16 & 35.15 & 35.01 & 33.82 & 29.15 & 15.14 \\
$\mathrm{~V}_{0}(\mathrm{~L})$ & 2.5 & 2.5 & 2.5 & 2.5 & 2.5 & 2.0 & 2.5 \\
$\mathrm{k}(\mathrm{L} / \mathrm{g})$ & 0.131 & 0.097 & 0.105 & 0.128 & 0.081 & 0.134 & 0.204 \\
$\mathrm{U}_{\mathrm{S}, 0}(\mathrm{~m} / \mathrm{h})$ & 16 & 11 & 18 & 135 & 11 & 9 & 47 \\
\hline
\end{tabular}


Table 3. Operational parameters of the pilot-scale UASB reactors from where the tested sludges were withdrawn, and calculated constants for sludge expansibility.

\begin{tabular}{lccccccc}
\hline \multicolumn{1}{c}{ Reactor } & $\mathrm{R}_{816}^{6}$ & $\mathrm{R}_{770}^{4}$ & $\mathrm{R}_{787}^{2}$ & $\mathrm{R}_{716}^{1}$ & $\mathrm{R}_{558}^{4}$ & $\mathrm{R}_{352}^{2}$ & $\mathrm{R}_{136}^{1}$ \\
\hline $\mathrm{h}_{0}(\mathrm{~m})$ & 30.5 & 27.8 & 23.8 & 21.5 & 26.4 & 21.0 & 16.4 \\
$\mathrm{~m}(\mathrm{~L} / \mathrm{g})$ & 1.957 & 1.588 & 1.518 & 1.595 & 1.271 & 1.610 & 1.843 \\
$\mathrm{~b}$ & 0.523 & 0.283 & 0.075 & 0.508 & 0.099 & 0.542 & 0.214 \\
$\mathrm{U}_{\mathrm{E}, 0}(\mathrm{~m} / \mathrm{h})$ & 0.3 & 0.5 & 0.8 & 3.2 & 0.8 & 0.3 & 0.6 \\
\hline
\end{tabular}

